\title{
Interpretasi Ayat-ayat Ihsān dalam Pengembangan Hukum Islam
}

\author{
Ahmad Mujahid dan Haeriyyah \\ Universitas Hasanuddin \\ ahmujahid69@gmail.com, haeriyyah@unhas.ac.id
}

\begin{abstract}
Abstrak
Artikel ini bertujuan untuk mengungkap makna-makna ayat tentang ihsān dan relasinya dalam pengembangan hukum Islam. Pendekatan yang dipakai adalah normatif dengan melacak ayat-ayat yang dimaksud. Hasil pembahasan menunjukkan bahwa pemaknaan ayat-ayat ihsān adalah berlaku baik terhadap pelaku tindak pidana yang dimaafkan oleh keluarga korban, penyelesaian rujuk atau cerai secara baik, orang-orang yang secara baik mengikuti orang-orang yang pertama masuk Islam di antara kaum Muhājirīn dan Ansār, berbuat baik kepada kedua orang tua dan keluarga, permintaan perlakuan baik dari orang-orang munafik, balasan kebaikan tidak lain hanyalah kebaikan, perintah untuk berbuat adil dan berbuat baik.

Kata kunci: Ihsān; Alquran; Hukum Islam.
\end{abstract}

\begin{abstract}
This article aims to reveal the meanings of the verse on ihsān and its relation in the development of Islamic law. The approach used is normative by tracking the verses in question. The results of the discussion showed that the meaning of the verses ihsān is to apply both to the perpetrators of crimes forgiven by the victim's family, the settlement of the reference or divorce properly, those who kindly follow the first people of Islam among the Muhäjirin and Ansār, doing good to both parents and families, requests for good treatment from the hypocrites, the reward of good is nothing but good, the command to do justice and to do good.
\end{abstract}

Keywords: Ihsān; Qur'ān; Islamic law.

\section{Pendahuluan}

Salah satu ajaran al-Qur'an yang berhubungan langsung dengan kepentingan umat manusia adalah perintah untuk berbuat baik kepada sesama manusia. Kebaikan dalam al-Qur'an selalu disimbolkan dengan kata al-ḥasan, al-khair, al-birr, al-ma'rūf serta al-ihsān. Kata alhasan dengan derivasinya dalam al-Qur'an berjumlah sekitar 180 yang ditemukan di 165 ayat. Sedangkan kata al-khair berjumlah sekitar 194 yang terdapat di 178 ayat dalam al-Qur'an dan kata al-birr berjumlah berjumlah 6 ayat serta kata al-ma'rūf digunakan sebanyak 37 kali. Sementara kata al-ihsān berjumlah 11 ayat dalam al-Qur'an. ${ }^{1}$

Penyebutan al-Qur'an yang berulangkali dan menggunakan berbagai istilah menunjukkan bahwa kebaikan tersebut memiliki urgensi yang mendalam sehingga al-Qur'an menggunakan

\footnotetext{
${ }^{1}$ Lihat Digital al-Qur'an. Lihat juga The Zekr Project, Qur'an Root Data Base
} 
term yang berbeda untuk menunjukkan makna kebaikan tersebut. Keragaman makna kebaikan yang digunakan oleh al-Qur'an menunjukkan bahwa kebaikan itu mempunyai tingkatantingkatan yang harus dicapai oleh seorang mukmin. Manfaat terasa bagi orang lain dan lingkungannya serta seluruh makhluk yang ada di alam ini.

Ihsān memiliki makna yang dalam dan untuk mencapai derajat muhsin, seseorang harus melalui fase-fase tertentu dalam berbuat kebaikan, berupa bentuk al-hasanah, al-khair, al-birr atau al-ma'rūf. Sekalipun penerapan ihsān terhadap sesama manusia dan antara hamba dengan Tuhan. Akan tetapi, hakikat ihsān itu adalah bentuk peleburan diri seorang hamba dengan Tuhannya.

Mengacu pada beberapa aspek yang dikemukakan di atas, maka permasalahan yang akan dikaji dalam artikel ini mengenai hakikat ihsān dalam al-Qur'an dan Bagaimana bentuk-bentuk $i h ̣ s \bar{n} n$ dan penerapan ihsān dalam pengembangan hukum Islam

\section{Pembahasan}

\section{Hakikat dan Penggunaan Ihsān dalam al-Qur'an}

Kata iḥsān dari segi pengertian etimologisnya berbentuk masdār (kata jadian) yang berasal dari akar kata dengan huruf h, s, n. Dari akar kata ini terbentuk lafal dengan sigah fi'il muta'addi (bentuk kata kerja transitif), yakni aḥsana yang berarti menjadikan sesuatu baik, atau memperbaiki, atau mempercantik sesuatu. ${ }^{2}$ Kata ihsān yang digunakam dalam al-Qur'an berjumlah 11 kali yang dapat berarti kemurahan hati, atau sedekah, atau derma. ${ }^{3}$ Kata ihsān juga dapat berarti segala perbuatan yang baik yang didasari oleh keimanan dan ketulusan menuju puncak kebaikan amal-amal perbuatan manusia.

Menurut al-Rāgib al-Asfahānī (w.502 H) bahwa kata ihsān dalam al-Qur'an digunakan dalam dua makna yaitu memberi nikmat kepada pihak lain dan perbuatan baik. ${ }^{4}$ Karena itu, kata ihsān lebih luas pengertiannya dari sekedar memberi nikmat atau nafkah bahkan maknanya lebih tinggi dari pada kandungan makna adil karena adil adalah memperlakukan orang lain sama

\footnotetext{
${ }^{2}$ Al-Husaiyn bin Muhammad al-Dāmagānīy, Iślāh al-Wujūh wa al-Nażāir fìy al-Qur'ān al-Karīm (Beyrūt: Dār al-'Ilm li al-Malāyīn, 1985), h. 131.

${ }^{3}$ Ahmad Warson Munawwir, al-Munawwir, Kamus Arab Indonesia (Yogyakarta: Pondok Pesantren alMunawwir, 1984), h. 285-286.

${ }^{4}$ Abū al-Qāsim al-Husain bin Muhammad al-Ma'rūf bi al-Rāghīb, al-Mufradāt fì Gharīb al-Qur'an yang di-rāji oleh Wāil Ahmad Abd. Rahmān (al-Qāhirah;Misr: al-Maktabat al-Taufiqiyyat, 2003), h. 126.
} 
dengan perlakuannya kepada diri anda. Sedangkan ihsān yaitu memperlakukan orang lain lebih baik dari pada perlakuannya terhadap anda. Adil adalah mengambil semua hak dan atau memberi semua hak orang lain sedangkan ihsān adalah memberi lebih banyak dari pada yang harus anda beri dan atau mengambil lebih sedikit dari yang seharusnya anda ambil. ${ }^{5}$

Sedangkan pengertian kata ihsān menurut al-Harrāli sebagaimana dikutip oleh al-Biqā’ $i$ adalah puncak kebaikan amal perbuatan. Jika pengertian ini ditempatkan pada seorang hamba, maka sifat dan perilaku ihsān akan tercapai saat seorang memandang dirinya pada orang lain, sehingga dia memberi untuknya apa yang seharusnya ia beri untuk dirinya pada diri orang lain. Sedang ihsān antara hamba dengan Allah adalah leburnya diri seorang hamba dengan Allah, sehingga yang ia lihat dalam dirinya dan diri orang lain adalah hanya Allah. Karenan itu, ihsān antara hamba dengan sesama manusia adalah bahwa dia tidak melihat lagi dirinya dan hanya melihat orang lain, siapa yang melihat dirinya pada posisi kebutuhan orang lain dan tidak melihat dirinya pada saat ia beribadah kepada Allah, maka dia itulah yang dinamai dengan muhsin yang berarti dia telah mencapai puncak dari segala amalnya. ${ }^{6}$

Dengan demikian, ihsān itu berarti suasana hati dan perilaku seseorang untuk senantiasa merasa dekat dengan Tuhan, sehingga setidaknya sesuai dengan aturan dan hukum Allah. ${ }^{7}$ Pengertian yang terakhir ini didasari pada dialog antara Malaikat Jibril dan Rasulullah, sebagaimana yang dijelaskan dalam hadis riwayat Bukhāri dari Umar bin al-Khattāb bahwa Rasulullah ditanya oleh Malaikat Jibril tentang ihsān yaitu;.

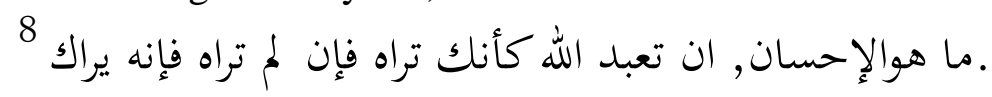

Hadis ini pada hakikatnya bertujuan untuk mengokohkan ibadah dan memelihara hak-hak Allah serta takut kepada-Nya juga merupakan pengakuan dalam hati atas kebesaran Allah dan keagungan-Nya pada saat melakukan ibadah kepada-Nya.

\footnotetext{
${ }^{5}$ Mardan, Wawasan al-Qur'an tentang Malapetaka (Jakarta: Pustaka Arif, 2009), h. 126.

${ }^{6}$ Lihat al-Biqā’i dalam M. Quraish Shihab, Tafsir al-Misbāh Pesan, Kesan dan Keserasian Al-Qur'an. Vol. 7. (Cet. IX ; Ciputat: Lentera Hati, 2007), h. 324.

${ }^{7}$ Azumardi Azra, Ensiklopedia Islam (ed) Jilid II (Cet. IX; Jakarta: PT. Ichtiar baru Van Hoeve, 2001), h. 178.

${ }^{8}$ Abū Abdillāh Muhammad bin Ismāil al-Bukhāri, Shahīh al-Bukhāri, Juz I (Cet. I; al-Riyād: Dār al-Alam al-Kutub, 1417 H/1996 M), h. 18-19.
} 
Dengan demikian, dapat ditegaskan bahwa ihsān lebih tinggi kedudukannya dibanding kata al-hasanah, al-khair, al-birr dan al-ma'rüf karena keempat term ini berada pada pengertian perbuatan baik saja. Namun, jika seseorang berbuat baik kepada orang lain dan mampu melebihkan kebaikan tersebut dari apa yang seharusnya ia berikan, maka itulah yang disebut dengan ihsān. Terkait ini, maka Nayf Ma'rūf mengatakan bahwa husn merupakan penamaan atas siapa saja yang mengerjakan yang diminta atau berkata sebuah perkataan dan dapat diterima secara ikhlas oleh pendengarnya. ${ }^{9}$ Sementara Toskhihiko Izutsu mengatakan bahwa kata hasan seperti kata khair, al-birr dan al-ma'rūf mempunyai cakupan yang sangat luas. Hasan adalah kata sifat yang dapat diterapkan pada hampir semua peristiwa apapun yang dianggap menyenangkan, memuaskan, indah, terpuji yang ruang lingkupnya mencakup kehidupan manusia yang bersifat religious dan bersifat duniawi. ${ }^{10}$

Hal itu menjadi penyebab Jibrīl tidak bertanya kepada Nabi dengan menggunakan lafal mā huwa al-hasan atau yang lainnya, karena ternyata al-hasan itu adalah kata sifat yang berlaku umum yang dapat diterapkan pada hampir semua peristiwa yang dianggap menyenangkan sedangkan ihsān adalah sesuatu yang khusus dan lebih tinggi kedudukannya dibanding kata hasan dan yang lainnya.

Kedudukan dan derajat ihsān yang lebih tinggi dibanding term al-hasanah, al-khair, albirr dan al-ma'rūf menjadikan term ihsān dijadikan motto oleh kalangan sufi dalam menjalani kehidupan tasawuf mereka dengan maksud untuk mendekatkan diri kepada Allah melalui kesempurnaan akhlak karena akhlak tersebut menjadi prinsip utama ihsān. Karena itu, untuk memperoleh ihsān diperlukan usaha sungguh-sungguh untuk mensucikan roh dan kalbunya sebab Allah yang Maha Suci hanya dapat didekati dengan roh dan kalbu yang suci, itulah sebabnya Abd. al-Karīm al-Jīllī memasukkan ihsān sebagai salah satu stasion atau maqām yang harus dilalui oleh seorang calon sufi dalam mencapai derajat insān Kāmil. ${ }^{11}$

\footnotetext{
${ }^{9}$ Lihat, Nayf Ma'rūf, al-Mu'jam al-Wasīt fľ̀ al-I'rāb (Beyrūt: Dār al-Nafāis, Cet. II, 1996), h. 126.

${ }^{10}$ Toskhihiko Izutsu, Ethico Religious Cencepts In The Qur'an (Malaysia: Islamic Book Trust, 2004), h. 257-258.

${ }^{11}$ Azumardi, Ensiklopedia ..., h. 179.
} 


\section{Bentuk-Bentuk Ihsān dalam al-Qur'an}

Penggunaan kata ihsān dalam al-Qur'an antara lain berbicara tentang kebaikan yang diberikan oleh keluarga korban terhadap pelaku tindak pidana, penyelesaian rujuk atau cerai secara baik, orang-orang yang secara baik mengikuti orang-orang yang pertama masuk Islam di antara kaum Muhājirīn dan Ansār, berbuat baik kepada kedua orang tua dan keluarga, kebaikan orang mu'min karena menerima permintaan damai dari orang-orang munafik, balasan kebaikan tidak lain hanyalah kebaikan, dan perintah untuk berbuat adil dan berbuat baik. Berikut ayat-ayat yang memuat bentuk-bentuk ihsān dalam al-Qur'an yaitu;

1. Berlaku baik terhadap pelaku tindak pidana yang dimaafkan oleh keluarga $\mathrm{k}$ orban dalam QS al-Baqarah/2: 178. Konsep ihsān yang terdapat dalam ayat tersebut mengandung makna yang dalam yaitu bahwa kisas adalah sesuatu yang wajib jika keluarga terbunuh menghendakinya tetapi pembalasan itu harus melalui pihak yang berwenang dengan ketetentuan bahwa orang merdeka dengan orang merdeka, hamba dengan hamba, tidak seperti adat Jahiliyah yang membunuh orang merdeka walaupun yang terbunuh orang adalah hamba sahaya atau jangan menuntut balas atas dua orang atau banyak jika yang terbunuh secar tidak sah hanya seorang karena kisas itu adalah persamaan. Namun, jika keluarga teraniaya ingin memaafkan dengan menggugurkan sanksi itu dan menggantinya dengan tebusan, maka hal itu dapat dibenarkan selama dilakukan dengan cara yang baik, yaitu pemberi maaf tidak menuntut tebusan yang melampaui batas. Demikian pula dengan yang membayar tebusan agar tidak menunda-nunda tanpa alasan atau mengurangi pembayaran tebusan. ${ }^{12}$

2. Penyelesaian rujuk atau cerai secara baik

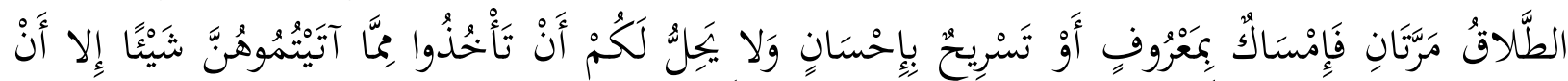

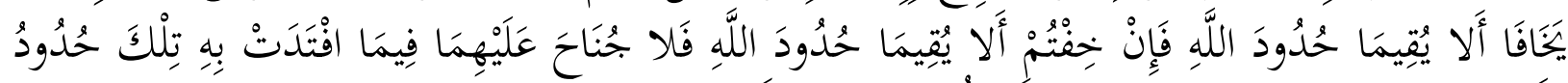

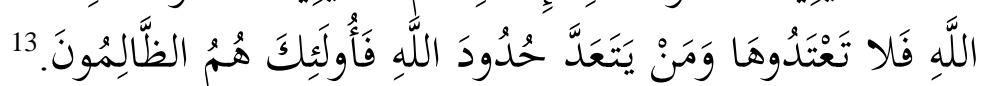

\section{Terjemahan:}

Talak (yang dapat dirujuki) dua kali. setelah itu boleh rujuk lagi dengan cara yang ma'ruf atau menceraikan dengan cara yang baik. tidak halal bagi kamu mengambil kembali

${ }^{12}$ Quraish Shihab, Al-Misbah, Vol. I., h. 393.

${ }^{13} \mathrm{QS}$ al-Baqarah (2): 229. 
sesuatu dari yang telah kamu berikan kepada mereka, kecuali kalau keduanya khawatir tidak akan dapat menjalankan hukum-hukum Allah. jika kamu khawatir bahwa keduanya (suami isteri) tidak dapat menjalankan hukum-hukum Allah, Maka tidak ada dosa atas keduanya tentang bayaran yang diberikan oleh isteri untuk menebus dirinya. Itulah hukumhukum Allah, Maka janganlah kamu melanggarnya. Barangsiapa yang melanggar hukumhukum Allah mereka Itulah orang-orang yang zalim.

Sementara makna ihsān dalam kasus cerai dalam QS al-Baqarah/2:229 adalah bahwa suami masih berkewajiban memberi mut'ah (pemberian nafkah kepada istrinya). Dengan demikian, istri tidak kehilangan dua hal yaitu cinta dan pemberian suaminya. Jika suami memang berketetapan hati untuk menceraikannya, maka lanjutan ayat menegaskan bahwa tidak boleh mengambil sebagian yang telah diberikan kepada mereka baik mas kawin maupun hadiah-hadiah karena hal tersebut bukan saja bertentangan dengan makna ihsān yang diperintahkan kepada kamu bahkan juga bertentangan dengan makna adil yang diperintahkan kepada semua pihak. ${ }^{14}$

3. Orang-orang yang secara baik mengikuti orang-orang yang pertama masuk Islam di antara kaum Muhājirīn dan Ansār

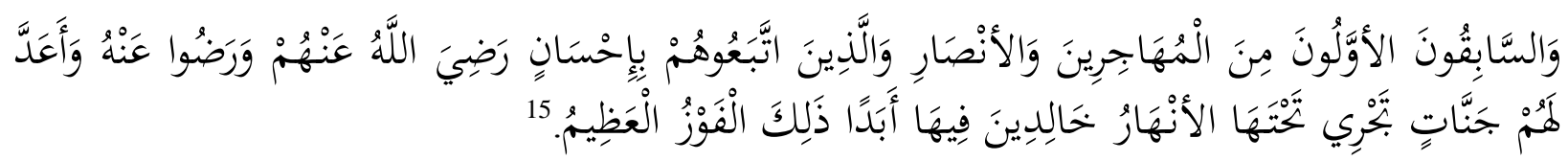

Terjemahan:

Orang-orang yang terdahulu lagi yang pertama-tama (masuk Islam) dari golongan muhajirin dan anshar dan orang-orang yang mengikuti mereka dengan baik, Allah ridha kepada mereka dan merekapun ridha kepada Allah dan Allah menyediakan bagi mereka surga-surga yang mengalir sungai-sungai di dalamnya selama-lamanya. mereka kekal di dalamnya. Itulah kemenangan yang besar.

Kata ihsān dalam ayat ini adalah orang-orang yang memeluk Islam setelah nabi dan mengikuti pengamalan orang-orang Muhājirīn dan Ansār dalam hal ketaatan dan pengorbanan mereka dalam membela Allah dan Rasul-Nya. Jika seorang muslim mengikuti tipe orang-orang Muhājirin dan Ansār dalam tersebut di atas, maka Allah akan ridha kepada mereka karena kesesuaian sikap dan prilaku mereka dengan apa yang dikehendaki oleh Allah dan merekapun ridha kepada Allah atas anugerah Allah yang menjadikan hati mereka dipenuhi oleh cahaya kebenaran sehingga mereka merasakan lezatnya iman.

${ }^{14}$ Quraish Shihab, Al-Misbāh..., h. 494.

${ }^{15}$ QS al-Taubah (9): $100 .$. 
4. Berbuat baik kepada kedua orang tua dan keluarga

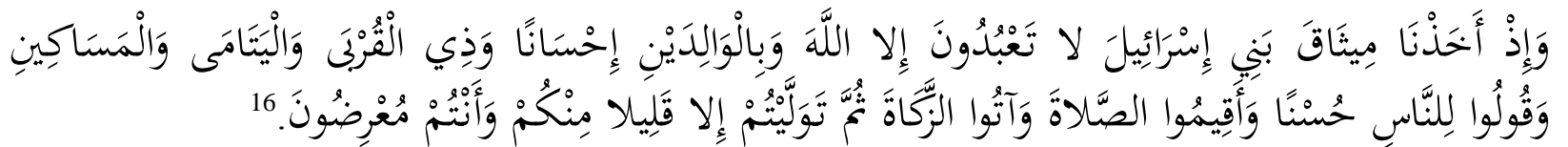

Terjemahan:

Dan (ingatlah), ketika Kami mengambil janji dari Bani Israil (yaitu): janganlah kamu menyembah selain Allah, dan berbuat kebaikanlah kepada ibu bapa, kaum kerabat, anakanak yatim, dan orang-orang miskin, serta ucapkanlah kata-kata yang baik kepada manusia, dirikanlah shalat dan tunaikanlah zakat. kemudian kamu tidak memenuhi janji itu, kecuali sebahagian kecil daripada kamu, dan kamu selalu berpaling.

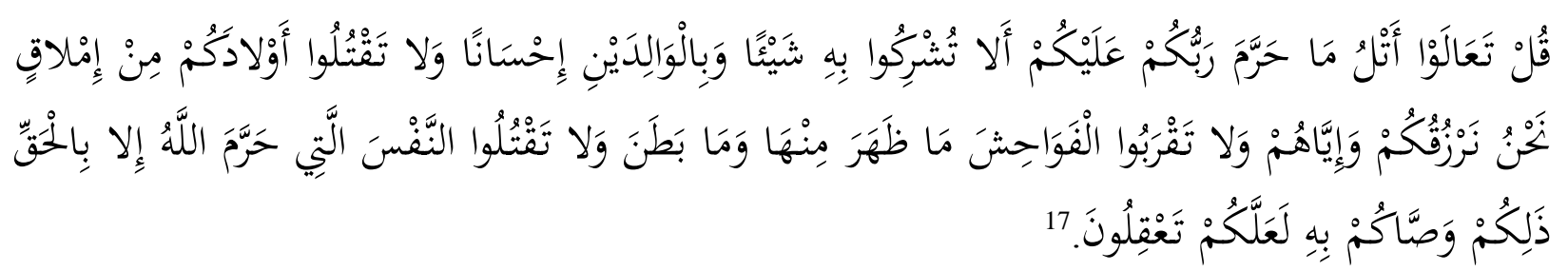

Terjemahan :

Katakanlah: "Marilah kubacakan apa yang diharamkan atas kamu oleh Tuhanmu Yaitu: janganlah kamu mempersekutukan sesuatu dengan Dia, berbuat baiklah terhadap kedua orang ibu bapa, dan janganlah kamu membunuh anak-anak kamu karena takut kemiskinan, Kami akan memberi rezki kepadamu dan kepada mereka, dan janganlah kamu mendekati perbuatan-perbuatan yang keji, baik yang nampak di antaranya maupun yang tersembunyi, dan janganlah kamu membunuh jiwa yang diharamkan Allah (membunuhnya) melainkan dengan sesuatu (sebab) yang benar". demikian itu yang diperintahkan kepadamu supaya kamu memahami(nya).

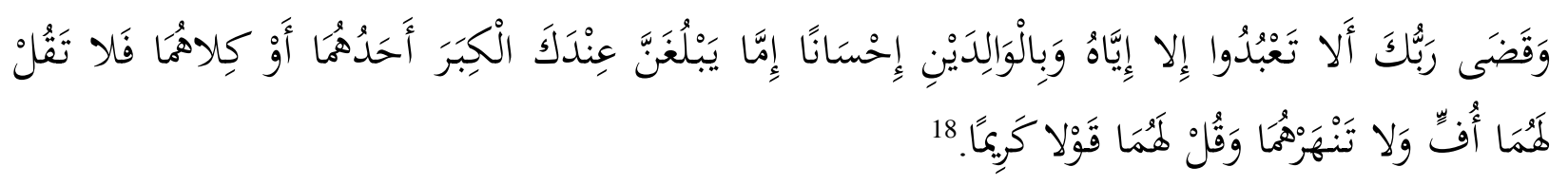

Terjemahan :

Dan Tuhanmu telah memerintahkan supaya kamu jangan menyembah selain Dia dan hendaklah kamu berbuat baik pada ibu bapakmu dengan sebaik-baiknya. jika salah seorang di antara keduanya atau Kedua-duanya sampai berumur lanjut dalam pemeliharaanmu, Maka sekali-kali janganlah kamu mengatakan kepada keduanya Perkataan "ah" dan janganlah kamu membentak mereka dan ucapkanlah kepada mereka Perkataan yang mulia.

Al-Ṭabārīy menjelaskan makna ihsān pada ayat-ayat tersebut di atas yaitu bahwa seorang anak tidak boleh berlaku sombong dan durhaka kepada kedua orang tua dan tidak pula

\footnotetext{
${ }^{16} \mathrm{QS}$ al-Baqarah (2) : 83.

${ }^{17} \mathrm{QS}$ al-An'ām (6) : 151.

${ }^{18} \mathrm{QS}$ al-Isrā (17): 23.
} 
mendurhakai Allah. ${ }^{19}$ Dengan demikian, ihsan memiliki lingkup pengertian yang cukup luas dan tidak terbatas hanya pada perbuatan memberi dalam bentuk materi. Di sisi lain, iḥsan juga mengisyaratkan pelakunya untuk berkata-kata secara santun, tidak angkuh serta sombong.

Wahbah al-Zuhaylīy menguraikan secara jelas bahwa iḥsān kepada kedua orang tua meliputi berbuat baik terhadap keduanya dan mengikuti permintaan mereka sesuai dengan kemampuan. Termasuk dalam kategori ini adalah bersikap lemah lembut dalam perangai dan tutur kata terhadap keduanya. ${ }^{20}$ Sementara Ibn 'Arabīy memandang bahwa perbuatan iḥsān kepada kedua orang tua merupakan bagian yang tak terpisahkan dari rukun-rukun agama, berbuat baik kepada keduanya meliputi bentuk verbal dan perbuatan. Dalam bentuk verbal, difahami dari ayat QS al-Isra (17) : 23 mengenai larangan untuk mengatakan "upp" atau bentakan. ${ }^{21}$ Kata "upp" adalah simbolisasi dari penggalan kata yang tidak sepantasnya kepada kedua orang tua ataupun salah seorang di antara mereka. Kata ini tidak bermakna apapun dalam teksnya, namun sangat berakibat dalam konteks perbuatan. Ia hanyalah penggalan kecil kebahasaan yang menggambarkan sikap tidak menurut kepada kedua orangtua.

Perintah untuk berbuat kebajikan (iḥsān) kepada kedua orang tua dilandasi beberapa alasan. Di antaranya adalah bahwa kedua orang tua telah berjasa besar dalam membesarkan dan memelihara anaknya, sebagaimana dipahami dari penjelasan ayat, yaitu ;

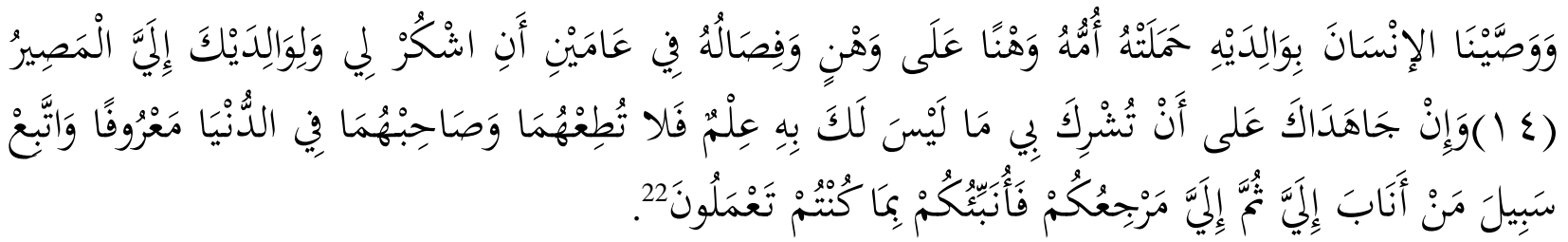

Terjemahan:

Dan Kami perintahkan kepada manusia (berbuat baik) kepada dua orang ibu- bapanya; ibunya telah mengandungnya dalam Keadaan lemah yang bertambah- tambah, dan menyapihnya dalam dua tahun[1180]. bersyukurlah kepadaku dan kepada dua orang ibu bapakmu, hanya kepada-Kulah kembalimu. Dan jika keduanya memaksamu untuk mempersekutukan dengan aku sesuatu yang tidak ada pengetahuanmu tentang itu, Maka janganlah kamu mengikuti keduanya, dan pergaulilah keduanya di dunia dengan baik, dan

\footnotetext{
${ }^{19}$ Lihat, Muhammad bin Jarīr al-Ṭabarīy, Tafsīr al-Ṭabarīy (t.tt, Mu'assasat al-Risālaț; Juz XVIII, 2000), h. 160.

${ }^{20}$ Wahbah Zuhāiliy, al-Tafsīr al-Munīr fìy al- 'Aqīdaț wa al-Syarī'aț wa al-Manhaj (Beyrūt: Dār al-Fikr alMișriyyat, Juz V, 1998), h. 63.

${ }^{21}$ Wahbah ..., h. 66.

${ }^{22}$ QS Luqmān (19): 14-15.
} 
ikutilah jalan orang yang kembali kepada-Ku, kemudian hanya kepada-Kulah kembalimu, Maka Kuberitakan kepadamu apa yang telah kamu kerjakan.

Perintah untuk berbuat iḥsān kepada kedua orang tua pada dua ayat terdahulu mengisyaratkan kepada lawan bicara bahwa perbuatan tersebut adalah sebuah keniscayaan mengingat peran dan penderitaan orang tua dalam mengasuh anaknya. Inilah yang menjadi penekanan kepada sang anak untuk berbakti kepada kedua orang tua mereka. Tahap selanjutnya, diisyaratkan kepada sang anak untuk memperhatikan batas-batas ketaatan yang dimaksud dengan informasi bahwa kesemua itu hanya pada aspek yang tidak mengarah kepada kesyirikan. AlQur'an telah menjelaskan kepada lawan bicara bahwa pada suatu ketika seorang anak harus memilih antara taat kepada kedua orang tua atau mensyerikatkan Allah. Al-Zamakhsyarīy menjelaskan bahwa ketaatan kepada kedua orang tua dibatasi dengan perintah untuk tidak mempersekutukan Allah. ${ }^{23}$ Langkah selanjutnya adalah bimbingan al-Qur'an yang mengarahkan lawan bicara untuk tetap mempertahankan sikap iḥsān kepada kedua orang tua di dunia, sekalipun orang tua memerintahkan mepersekutukan Allah.

5. Permintaan perlakuan baik dari orang-orang munafik

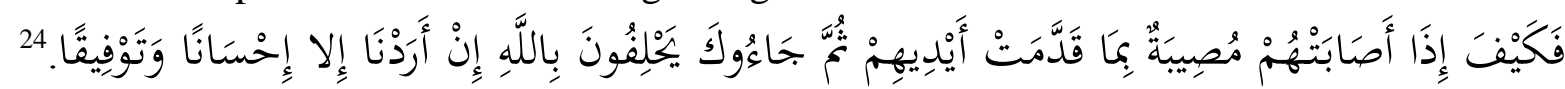

Terjemahn:

Maka Bagaimanakah halnya apabila mereka (orang-orang munafik) ditimpa sesuatu musibah disebabkan perbuatan tangan mereka sendiri, kemudian mereka datang kepadamu sambil bersumpah: "Demi Allah, Kami sekali-kali tidak menghendaki selain penyelesaian yang baik dan perdamaian yang sempurna".

Makna ihsān dalam ayat ini adalah bahwa permintaan damai dari orang-orang munafiq tidak dapat dipercaya karena mereka hanya bersumpah palsu untuk mendapatkan kebaikan dari orang Islam ketika mereka tertimpa musibah, sementara mereka tetap menolak ketika diajak kepada tuntutan ilāhi.

${ }^{23}$ Lihat, Abū al-Qāsim Mahmūd bin 'Amru bin Aḥmad al-Zamakhsyarīy Jār Allah, Tafsīr al-Kasysyāf (t.tt: Muwāqi' al-Tafāsīr, t.th), h. 191.

${ }^{24} \mathrm{QS}$ al-Nisa (4) : 62. 
6. Balasan kebaikan tidak lain hanyalah kebaikan

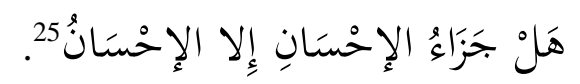

Terjemahan:

Tidak ada Balasan kebaikan kecuali kebaikan (pula).

Ayat ini menggunakan kata ihsān sebanyak dua kali yang menurut rumus ulama bahwa bila ada suatu kata yang berbentuk ma'rīfah lalu kata itu diulang dalam satu kalimat, maka makna kata yang disebut pertama itu sama dengan makna kata yang disebut di kali kedua. Sebaliknya, jika kata itu nakirah, maka yang kedua berbeda dengan yang pertama. Ayat ini merupakan pengecualian dari rumus tersebut, kata ihsān di sini diulangi dua kali namun makna kata yang sama tersebut berbeda, kata ihsān yang pertama berarti perbuatan baik (amal-amal saleh) dan kata ihsān yang kedua bernakna penganugrahan yang baik (kenikmatan surgawi). ${ }^{26}$

7. Perintah untuk berbuat adil dan berbuat baik dalam QS al/Nahl:69.

Kata ihsān dalam ayat ini berdampingan dengan kata adil, sehingga memberi makna bahwa perintah berbuat adil itu harus berlandaskan pada kebaikan, yaitu keadilan yang bernilai lebih dibanding yang seharusnya ia berikan kepada orang lain. Quraish Shihab mengatakan bahwa adil dalam ayat tersebut adalah menempatkan sesuatu pada tempatnya, sementara berbuat kebajikan adalah memperlakukan sesuatu melebihi keadilan. Dengan kata lain, seseorang karena kesalahannya dapat diperlakukan baik tanpa memperdulikan kesalahannya. ${ }^{27}$ Pengertian ini dibangun dari pernyataan Ali bin Abī Țālib bahwa adil menempatkan sesuatu pada tempatnya, sedang berbuat kebajikan adalah menempatkan sesuatu bukan pada tempatnya. ${ }^{28}$ Dengan dasar ini pula, maka Rasulullah tetap menjatuhkan hukuman kepada pencuri, meski pencuri tersebut telah mengembalikan barang yang telah ia curi. ${ }^{29}$

Salah satu bentuk iḥsān terhadap kerabat dekat dalam ayat ini adalah dengan memberi derma kepada kerabat terdekat, kaum miskin dan Ibnu sabil. Dalam pandangan Ibnu Kașīr, perbuatan ihsān kepada kedua orang tua dipersamakan oleh Allah dengan pemberian derma

\footnotetext{
${ }^{25}$ QS al-Rahmān (55): 60.

${ }^{26}$ Shihab, Al-Misbāh, Vol. 13, h. 532.

${ }^{27}$ M. Quraish Shihab, Wawasan Al-Quran; Tafsir Maudhu'I atas Pelbagai Persoalan Umat (Jakarta: Cet. XV, Mizan, 2004 M.), h. 124

${ }^{28}$ Shihab..., h. 124.

${ }^{29}$ Shihab..., h. 12 ..
} 
kepada kerabat terdekat pada ayat ini. ${ }^{30}$ Hal ini didasarkan pada hadis Nabi yang menjelaskan tentang berbagai hal terkait dengan berbuat ihsān kepada keduanya. Lebih jauh, ketika ayat ini diturunkan, Rasulullah Saw memanggil Fatimah puteri beliau dan serta memberinya sesuatu. ${ }^{31}$

Bentuk ihsān kepada kerabat dan anak yatim juga dikemukakan secara jelas dalam QS. Al-Nisā (4) ; 32. Ayat ini mengisyaratkan bahwa pada waktu diadakan pembagian terhadap harta warisan dan pusaka, maka Allah kemudian menjelaskan bahwa perbuatan dimaksud dapat saja dilaksanakan dalam jumlah terbatas pula. Jumlah dimaksud tidak melebihi sekedarnya, yaitu sepertiga dari harta atau pusaka yang akan diwariskan kepada para ahli waris.

Pebuatan ihsān kepada isteri-isteri dengan jalan tidak memaksa mereka untuk dipusakai, atau berbuat sesuatu yang menyusahkan mereka guna menarik kembali segala pemberian yang telah diserahkan kepadanya dalam ikatan perkawinan. Peluang untuk menarik kembali pemberian (mahar) oleh ayat tersebut dibuka lebar kembali ketika terbukti si isteri bersangkutan, nyata-nyata berbuat kekejian.

Format lain dari berbuat ihsān kepada para isteri diatur ketika terjadi putusnya perkawinan karena adanya talak. QS. Al-Ṭalāq (65) : 1-2 menjelaskan berbagai hal yang bertalian dengan perlakuan kepada isteri-isteri yang ditalak, yaitu dua hal yang mungkin terjadi yakni bersatu (rujuk) kembali atau berpisah dengan jalan yang ma'rūf . Term ma'rüf ini dimaknai oleh para mufassir sebagai jalan yang bijak untuk kembali. Meski khitab ayat mengarah ke Nabi, namun dapat dipahami bahwa khitab tersebut berlaku universal. Berdasarkan pendekatan asbāb al-nużūl al-āyat diriwayatkan bahwa Rasulullah saat itu memutuskan untuk bercerai dari Hafsah, maka Allah kemudian memerintahkan Nabi untuk segera merujuk wanita tersebut berdasarkan kabar bahwa Hafsah adalah wanita yang akan mendampingi beliau di akhirat kelak. $^{32}$

Dalam kondisi terjadi perceraian pun, al-Qur'an masih memerintahkan pihak suami untuk berbuat $i h ̣ s a ̄ n$ kepada isteri-isteri mereka, suami tetap diminta untuk memberi nafkah bagi isteriisteri yang sedang hamil hingga ia melahirkan anaknya. Suami juga diminta untuk membayar upah sang isteri jika kemudian ia memutuskan untuk menyapikan anak mereka, bahkan dalam

\footnotetext{
${ }^{30}$ Lihat, Abīy al-Fidā' Ismā’̄̄l bin 'Amr bin Kas̀īr al-Quraysy al-Dimasyqi, Tafsìr Ibn Kas̄īr (Beyrūt: Dār Tayyibat Li al-Nasyr wa al-Tauzi', Juz V, 1999), h. 65

${ }^{31}$ al-Quraysy ..., h. 65.

${ }^{32}$ al-Quraysy, h. 142.
} 
pandangan Ibn Kasiīr kalaupun ada keinginan suami untuk menceraikan isteri mereka, diharuskan kepada suami untuk menjaga isteri mereka dalam rumah-rumah mereka, yang dipahami dari pemahaman Ibn "Abbās terhadap kata wujdun dalam teks ayat yang bermakna "rumah". 33

Jika pembicaraan iḥsān kepada isteri pada ayat-ayat yang terdapat dalam QS. Al-Ṭalāq berbicara tentang cara penyelesaian konflik keluarga, maka pada QS al-Baqarat dibicarakan tentang bagaimana mempergauli isteri-isteri tersebut. Pembicaraan dimaksud berawal dari keterangan bahwa pada malam bulan puasa dihalalkan untuk mendatangi isteri-isteri. Kebolehan ini didasarkan pada kenyataan bahwa sesungguhnya para suami tersebut pasti tidak akan mampu untuk menahan hawa nafsu mereka. Oleh itu, Allah kemudian memberi pengampunan kepada hamba-Nya dan membiarkan mereka mendekati isteri-isteri mereka pada malam bulan Ramadhan. Dalam kondisi tertentu, seorang suami sedang melaksanakan i'tikāf di masjid, berlaku larangan untuk bercampur dengan isteri-isteri mereka, sebagaimana penjelasan QS alBaqarah (2) : 187. Demikian pula dengan ihsān terhadap isteri-isteri yang sedang haid, yaitu larangan bagi suami untuk mendekati isteri-isteri mereka. Penetapan ini didasarkan pada keterangan bahwa dalam kondisi ini, para isteri sedang mengalami masa tidak bersih, sebagaimana keterangan al-Qur'an dalam QS al-Baqarah (2) : 222.

Bentuk-bentuk iḥsān yang telah dikemukakan dalam ayat-ayat di atas harus diiringi dengan ucapkan dan perkataan baik kepada sesama manusia. Menurut Ibnu Jarīr dari al-Ḍaḥhāk dari Ibn al-'Abbās menjelaskan bahwa maksud dari kalimat adalah perintah Allah untuk menyeru kepada kebaikan dan mencegah dari perbuatan munkar, begitupula pendapat yang dikemukakan oleh Ibn Abī Khātim dari Ibn al-Abbās. ${ }^{34}$ Sementara itu, al-Bayhāāìy dalam sya’b al-Imān dari 'Alīy bin Abīy Ṭālib mengomentari bahwa maksud dari term ini adalah "manusia secara keseluruhan". ${ }^{35}$

\footnotetext{
${ }^{33}$ al-Quraysy , h. 152

${ }^{34}$ Jalāl al-Dīn 'Abd al-Rahmān bin Abī Bakr al-Suyūṭīy, al-Dur al-Ma'šùr Fì Tafsīr al-Ma'sūur Juz I, (Beyrūt: Dār al-Kutub al-'Ilmiyyat, Cet. I, 1990), h. 165.

${ }^{35}$ Șubhīy 'Abd al-Raūf 'Așar dalam "Mu'jam al-Maudū'iy li 'Ayāt al-Qur'ān al-Karīm” mengelompokkan bentuk-bentuk ihsān dalam ayat, antara lain adalah bahwa bentuk-bentuk al-ihsān itu antara lain adalah ihsān kepada kedua orang tua, kepada Karib Kerabat, kepada Anak-anak yatim, kepada Orang-orang miskin, kepada Para tetangga, kepada Ibnu Sabīl dan Para Peminta-minta, kepada Para anak, kepada Para Isteri, kepada para Budak dan Hamba Sahaya, dan kepada Umum. Șubhīy 'Abd al-Raūf 'Așar, Mu'jam al-Maudūu'iy li 'Āyāt al-Qur'ān al-Karīm (t.tp: Dār al-Faḍilaț, t.th.), h. 186-203.
} 


\section{Kesimpulan}

Hakikat ihsān dalam al-Qur'an adalah leburnya diri seorang hamba dengan Tuhan-Nya, sehingga ia melihat Tuhan pada dirinya dan diri orang lain. Ihsān menjadi puncak amal perbuatan seorang muslim sehingga mencapai derajat muhsin. Bentuk-bentuk ihsān adalah berlaku baik terhadap pelaku tindak pidana yang dimaafkan oleh keluarga korban, penyelesaian rujuk atau cerai secara baik, Orang-orang yang secara baik mengikuti orang-orang yang pertama masuk Islam di antara kaum Muhājirīn dan Ansār, berbuat baik kepada kedua orang tua dan keluarga, permintaan perlakuan baik dari orang-orang munafik, balasan kebaikan tidak lain hanyalah kebaikan, perintah untuk berbuat adil dan berbuat baik.

\section{DAFTAR PUSTAKA}

Așar, Șubhīy 'Abd al-Raūf, Mu'jam al-Mauḍū'iy li 'Āyāt al-Qur'ān al-Karīm (t.tp: Dār alFaḍīlat, t.th.)

Azra, Azumardi, Ensiklopedia Islam (ed) Jilid II. Cet. IX; Jakarta: PT. Ichtiar baru Van Hoeve, 2001.

al-Bukhāri, Abū Abdillāh Muhammad bin Ismāil. Shahīh al-Bukhāri, Juz I. Cet. I; al- $\quad$ Riyād: Dār al- Alam al-Kutub, 1417 H/1996 M.

Departemen Agama RI., Al-Qur'an dan Terjemahnya (Semarang: Toha Putra, 2009)

al-Dāmagān̄y,Muhammad, Iślāh al-Wujūh wa al-Nażāir fìy al-Qur'ān al-Karīm (Beyrūt: Dār al-'Ilm li al-Malāyīn, 1985)

al-Dimasyqi, Abīy al-Fidā' Ismā’̄̄l bin 'Amr bin Kas̀īr al-Quraysy , Tafsīr Ibn Kașīr (Beyrūt: Dār Ṭayyibat Li al-Nasyr wa al-Tauzi’, Juz V, 1999)

Izutsu, Toskhihiko. Ethico Religious Cencepts In The Qur'an. Malaysia: Islamic Book Trust, 2004.

Jār Allah, Abū al-Qāsim Mahmūd bin 'Amru bin Aḥmad al-Zamakhsyarīy, Tafsīr al-Kasysyāf. t.tt: Muwāqi’ al-Tafāsīr, t.th.

Ma'rūf, Nayf, al-Mu'jam al-Wasīt fìy al-I'rāb (Beyrūt: Dār al-Nafāis, Cet. II, 1996.

Mardan, Wawasan al-Qur'an tentang Malapetaka. Jakarta: Pustaka Arif, 2009.

Munawwir, Ahmad Warson. al-Munawwir, Kamus Arab Indonesia. Yogyakarta: Pondok Pesantren al- Munawwir, 1984.

al-Rāghīb, Abū al-Qāsim al-Husain bin Muhammad. al-Ma'rūf bi al-Mufradāt fì Gharīb alQur'an yang di-rāji oleh Wāil Ahmad Abd. Rahmān. al- Qāhirah;Misr: al-Maktabat al-Taufiqiyyat, 2003.

Shihab, M. Quraish, Wawasan Al-Quran; Tafsir Maudhu'I atas Pelbagai Persoalan Umat (Jakarta: Cet. XV, Mizan, 2004 M.)

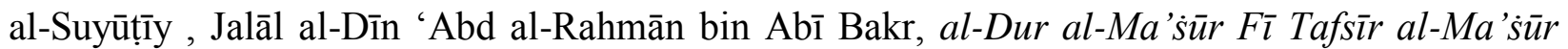
Juz I, (Beyrūt: Dār al-Kutub al-'Ilmiyyat, Cet. I, 1990)

al-Ṭabarīy, Muḥammad bin Jarīr, Tafsīr al-Ṭabarīy (t.tt, Mu'assasat al-Risālat; Juz XVIII, 2000) 
al-Zuhaylīy, Wahbah, al-Tafsīr al-Munīr fìy al- 'Aqīdat wa al-Syarī'at wa al-Manhaj (Beyrūt: Dār al-Fikr al-Mișriyyat, Juz V, 1998) 